Haya: The Saudi Journal of Life Sciences

Abbreviated Key Title: Haya Saudi J Life Sci ISSN 2415-623X (Print) |ISSN 2415-6221 (Online) Scholars Middle East Publishers, Dubai, United Arab Emirates Journal homepage: https://saudijournals.com/sjls

Original Research Article

\title{
Effects of Crude Aqueous Extracts of Pyrenacantha Staudtii and Trichilia Monadelpha on Visceral Organs of Albino Mice
} Olorunniyi $\mathrm{OF}^{*}$

Department of Zoology and Environmental Biology, Ekiti State University, Ado-Ekiti, Ekiti State, Nigeria

DOI: $\underline{10.36348 / \mathrm{sj} 1 \mathrm{l} .2020 . \mathrm{v} 05 \mathrm{i} 05.001}$

| Received: 27.04.2020 | Accepted: 07.05.2020 | Published: 12.05.2020

*Corresponding author: Olorunniyi OF

\section{Abstract}

Pyrenacantha staudtii and Trichilia monadelpha are herbal plants used indiscriminately to treat malaria by local people in Nigeria. Hence the need to examine the effects of these plants on the visceral organs of mice in order to determine their safety use. Crude aqueous extracts of the plants were prepared. Different concentrations such as $500 \mathrm{mg} / \mathrm{Kg}$, $800 \mathrm{mg} / \mathrm{Kg} 1000 \mathrm{mg} / \mathrm{Kg}, 2000 \mathrm{mg} / \mathrm{Kg}$ and $4000 \mathrm{mg} / \mathrm{Kg}$ of the extracts were separately administered to mice in different groups. After $24 \mathrm{~h}$ post-administration of the extracts, the mice were sacrificed to examine the histology of their visceral organs. No mortality was recorded among the treated mice $24 \mathrm{~h}$ post-administration of the extracts. There was no lesion on the lung and heart tissues of the treated mice. The extracts of $P$. staudtii caused necrosis in the liver and kidney tissues at high concentration. But no necrosis was observed in the liver and kidney tissues of mice administered with $T$. monadelpha extract. Generally, there were cellular infiltrations in the liver and kidney tissues of the mice administered with the extracts of both $P$. staudtii and T. monadelpha. No lesion was seen in the tissues of untreated mice. Both $P$. staudtii and $T$. monadelpha appeared to be toxic at high concentration. Indiscriminate use of these plants without standard measurement should be discouraged.

Keywords: Pyrenacantha staudtii, Trichilia monadelpha, toxicity, plant extract, histology, viscerals.

Copyright @ 2020: This is an open-access article distributed under the terms of the Creative Commons Attribution license which permits unrestricted use, distribution, and reproduction in any medium for non-commercial use (NonCommercial, or CC-BY-NC) provided the original author and source are credited.

\section{INTRODUCTION}

Men learnt to exploit plants for medicine, almost as early as they cultivated them for food [1] Traditional medicine has not only played a vital role in providing healing but has also contributed to the discovery of most pharmaceutically active substances in plants [2, 3] which have been used in the commercial production of drugs. Medicinal plant species also show diversity in their parts used for the treatment of diseases, with leaves, roots and barks being the most commonly harvested parts used in herbal medicine preparation [4]. Nigeria has rich flora diversity and many of the plant species are used by some local people for medicinal purposes. Some of the plant species are used for malaria treatment across all ethnic and cultural groups in the country [5].

Pyrenacantha staudtii and Trichilia monadelpha were among the herbal plants used for the management of malaria in Ekiti State, Nigeria [6]. Both $P$. staudtii and T. monadelpha have been reported to possess antimalarial properties [7, 8]. But these plants are used indiscriminately without any standardized measurement or dosage to treat malaria [6]. This necessitated the design of this study with the aim to determine the safety use of these herbal plants in antimalarial recipes among the local people in Nigeria. Observing the histological changes in the visceral organs of laboratory animals to a drug in an acute toxicity test is one of the criteria used to determine the safety use of drug in humans. Hence the need to examine the histology of the visceral organs of mice administered with the crude aqueous extracts of $P$. staudtii and T. monadelpha in an acute toxicity test.

\section{METHODS AND MATERIALS}

Collection and Identification of Plants

$P$. staudtii and T. monadelpha were collected from Ajowa farm at Ido-Ekiti in Ekiti State, Nigeria. The plants were identified and authenticated at the Herbarium of Forestry Research Institute of Nigeria (FRIN), Ibadan where voucher specimens were deposited with the following numbers: Pyrenacantha staudtii, Icananaceae (FHI No 108805) and Trichilia monadelpha, Meliaceae (FHI No 108844). The parts of the plants used for the study were the leaves of Pyrenacantha staudtii and stem bark of Trichilia 
monadelpha in accordance with the way they are used by the local people [6].

\section{Preparation of Crude Aqueous Extracts of the Plants}

The parts of the plants (i.e. leaves and bark) were sorted to remove contaminants, dead matter or sand particles and they were air-dried inside a ventilated room before grounded into a coarse powder. The coarse powder $(200 \mathrm{~g})$ was extracted using distilled water for 48 hours at room temperature. The extract was filtered to obtain a filtrate which was concentrated to dryness over a water bath [7], [8]. Appropriate concentrations from each of the plant extracts were made in water and used in the experiment.

\section{Acute Toxicity Tests of Crude Aqueous Extracts of Pyrenacantha staudtii and Trichilia monadelpha in mice}

Adult Swiss albino mice of average weight of $25 \mathrm{~g}$ were divided into six groups for each experimental test of P. staudtii and T. monadelpha extracts. Each cage of the six groups consisted of five mice. The mice were labeled using dilute picric acid. The acute toxicity tests of the crude aqueous extracts of $P$. staudtii and $T$. monadelpha were separately carried out. The crude extract of the plant with the concentration of $500 \mathrm{mg} / \mathrm{Kg}, 800 \mathrm{mg} / \mathrm{Kg}, 1000 \mathrm{mg} / \mathrm{Kg}, 2000 \mathrm{mg} / \mathrm{Kg}$ and $4000 \mathrm{mg} / \mathrm{Kg}$ body weight of mice were separately administered to the mice in the respective Group 1-5 via an oral route with the aid of a cannula. Mice in Group 6 which served as a control were given water as placebo. Animals were observed for 24 hours for any changes. After 24 hours of the administration of plant extracts, the animals were sacrificed to collect the visceral organs which were lung, heart, liver and kidney for histological examination as described by $\mathrm{Gu}$ et al. [9]. The organs were carefully removed and fixed in $10 \%$ neutral buffered formalin. Afterwards, the organs were gradually dehydrated in ethanol solution at different concentrations. They were immersed in xylol, and then embedded in paraffin. Serial sections, $5 \mu \mathrm{m}$ thick was prepared and stained with hematoxylin-eosin on a microscope slide.

\section{RESULTS AND DISCUSSION}

No mortality was recorded in all the mice after the oral administration of the crude aqueous extracts of both $P$. staudtii and $T$. monadelpha 24 hours postadministration even at the highest concentration of $4000 \mathrm{mg} / \mathrm{Kg}$ body weight of mice. This indicates that the oral median lethal dose $\left(\mathrm{LD}_{50}\right)$ of the two plants extracts were greater than $4000 \mathrm{mg} / \mathrm{Kg}$ body weight. This result was similar to the findings of Akuodor et al. [10] where no mortality was reported with mice administered with $5000 \mathrm{mg} / \mathrm{Kg}$ of ethanolic extract of a plant, Verbena hastate. The $\mathrm{LD}_{50}$ of Alstonia boonei, a plant commonly used in antimalarial recipes in Southwest Nigeria was also estimated to be $\geq$ $5000 \mathrm{mg} / \mathrm{Kg}$ body weight [11]. Using $\mathrm{LD}_{50}$ to ascertain the safety use of a testing plant extract in acute toxicity test may not be satisfactory enough to indicate that such plant extract is non-toxic.

The heart tissues of both the treated and the untreated animals (control) did not show any visible lesion. However, the lung tissues of the mice administered with $800 \mathrm{mg} / \mathrm{Kg}$ of $P$. staudtii extract showed moderate congestion of the inter-alveolar septum while those administered with 1000, 2000 and $4000 \mathrm{mg} / \mathrm{Kg}$ showed moderate interstitial congestion. But no lesion was seen on the lung tissues of mice administered with $500 \mathrm{mg} / \mathrm{Kg}$ of $P$. staudtii extract and the mice administered with various concentrations of $T$. monadelpha extract. The lung tissues of the untreated mice also did not show visible lesion. However, the effects of the two plant extracts on liver tissues were significant. At concentrations of 500 and $800 \mathrm{mg} / \mathrm{Kg}, P$. staudtii extract caused a mild periportal cellular infiltration by mononuclear cells. Also, the portal canal of the liver was moderately congested. The effect was however very significant at higher concentrations. At $1000 \mathrm{mg} / \mathrm{Kg}$, there was a diffuse hepatic degeneration and necrosis, with severe periportal cellular infiltration by mononuclear cells. At 2000 and $4000 \mathrm{mg} / \mathrm{kg}$, the liver tissues showed severe hepatic necrosis with severe portal congestion and periportal cellular infiltration by mononuclear cells (Figure 1).

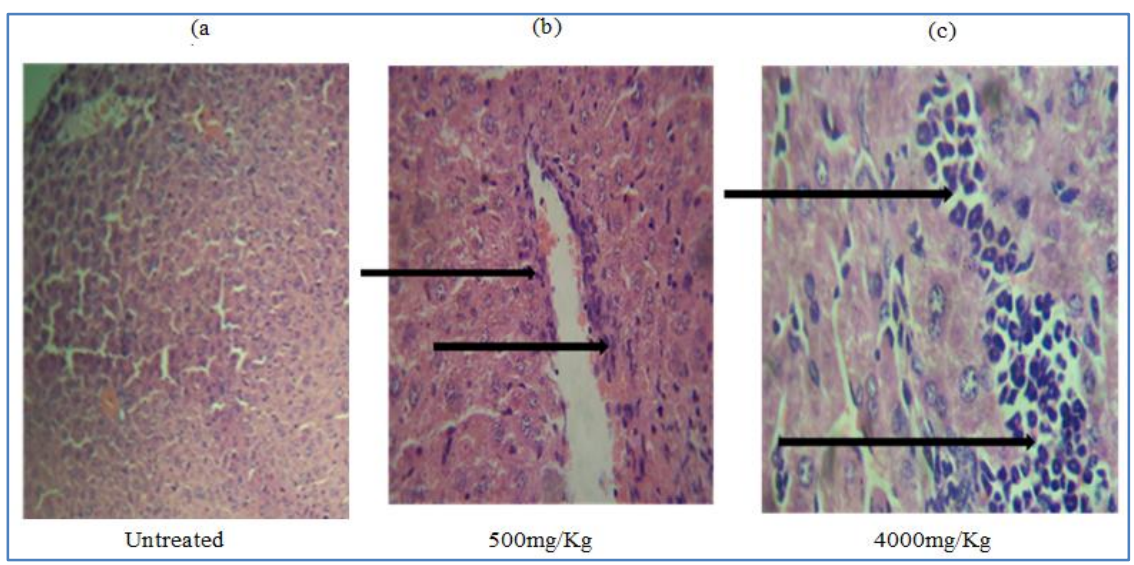

Fig-1: Micrograph of liver tissues of mice administered with $P$. staudtii extract. (a) Tissues show no lesion. (b) Arrows show the mild periportal cellular infiltration. (c) Arrows show severe hepatic necrosis with diffuse and periportal cellular infiltration by mononuclear cells 
In the case of $T$. monadelpha, the extract caused severe portal congestion and periportal cellular infiltration on the liver tissues by mononuclear cells even at $800 \mathrm{mg} / \mathrm{Kg}$ (Figure 2). There was moderate portal congestion and periportal cellular infiltration by mononuclear cells in the liver tissues of the mice administered with $500 \mathrm{mg} / \mathrm{Kg}$. However, unlike the extract of $P$. staudtii, the extract of $T$. monadelpha did not cause necrosis at any concentration even at $4000 \mathrm{mg} / \mathrm{Kg}$ body weight of the experimental animals. No lesion was seen on the liver tissues of the untreated animals.

The kidney tissues of the mice administered with $4000 \mathrm{mg} / \mathrm{Kg}$ of $P$. staudtii extract showed multiple foci of interstitial cellular infiltration, some tubules are necrotic while those of $2000 \mathrm{mg} / \mathrm{Kg}$ showed severe cortical congestion and severe interstitial cellular infiltration. Mice that were administered with $1000 \mathrm{mg} / \mathrm{Kg}$ only showed moderate renal cortical congestion and no visible lesions were seen in the mice administered with $800 \mathrm{mg} / \mathrm{Kg}, 500 \mathrm{mg} / \mathrm{Kg}$ and the untreated mice (Figure 3). However, at concentration of $4000 \mathrm{mg} / \mathrm{Kg}$ of $T$. monadelpha extract, the kidney tissues only showed a mild renal cortical congestion (Figure 3). But no visible lesion was seen in the kidney tissues of the mice administered with 500, 1000 and $2000 \mathrm{mg} / \mathrm{Kg}$ body weight of mice.

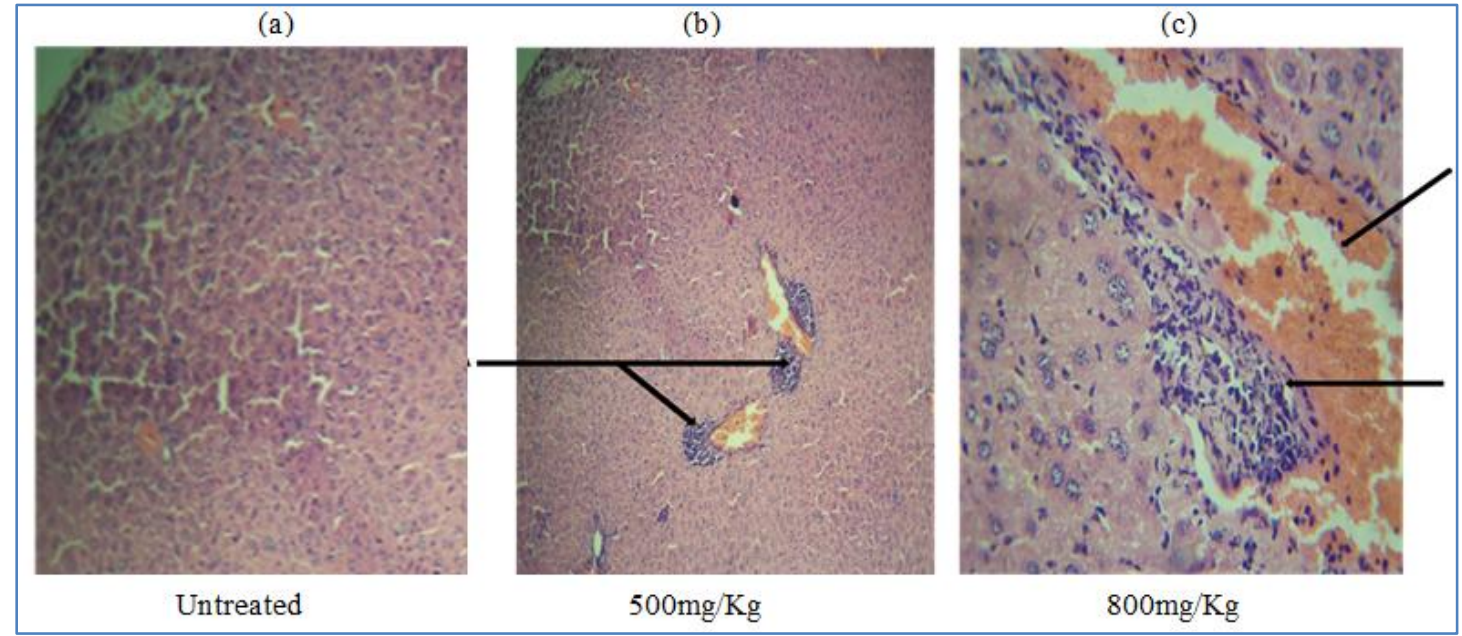

Fig-2: Micrograph of liver tissues of mice administered with T. monadelpha extract (a) Tissues show no lesion in the untreated mice. (b) Arrows show moderate portal congestion and periportal cellular infiltration by mononuclear cells. (c) Arrow show severe portal congestion and periportal cellular infiltration by mononuclear cells

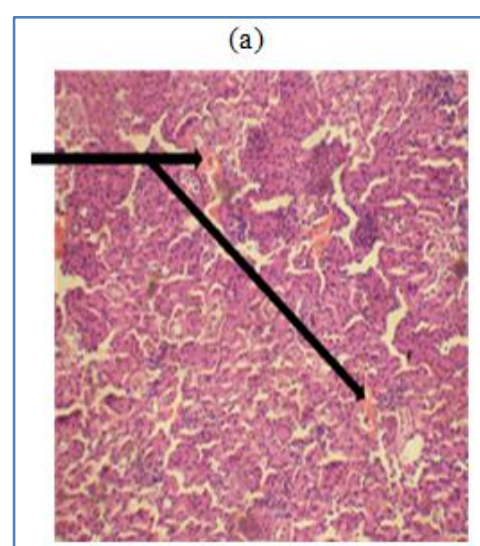

$T$. (b)

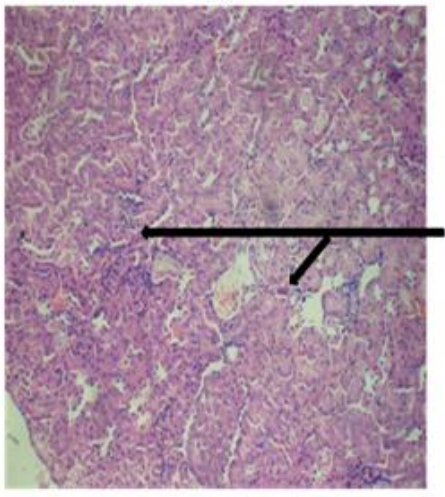

$P$.

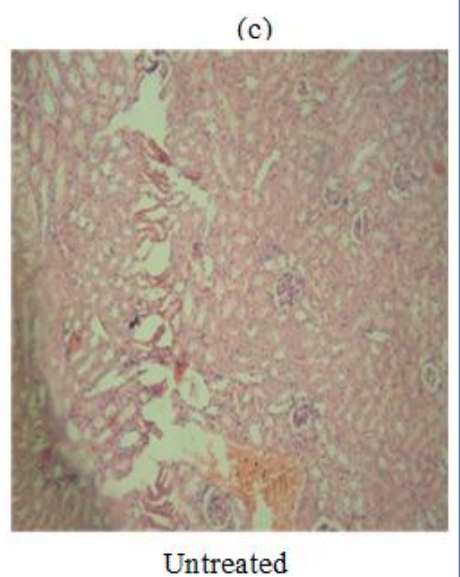

Fig-3: Micrograph of kidney tissues of mice administered with $4000 \mathrm{mg} / \mathrm{Kg}$ of extracts of $T$. monadelpha, $P$. staudtii and the untreated mice. (a) Arrows show mild renal cortical congestion. (b) Arrows show multiple foci of interstitial cellular infiltration. (c) Tissues show no lesion in the untreated mice

Toxicity studies are considered very important in drug development while considering the indiscriminately use of herbal medicines by local people without due consideration to the harmful effects that could possibly associate with the use of such herbs $[12,13]$. After 24 hours of treatment with the crude aqueous extracts of $P$. staudtii leaves, there were treatment-related changes in the histological structure of the liver and the kidney tissues between the control and the treated groups. Even though that there was no significant damage in the heart and lung tissues of the experimental animals, the hepatic degeneration, severe portal congestion and necrosis, with severe periportal cellular infiltration observed in the liver tissues of 
animals administered with $P$. staudtii extract suggest the toxicity properties of the plant at a high concentration. The infiltration by mononuclear cells might be due to a response elicited by the immune system of the animals. This caused the inflammation of the liver otherwise referred to as hepatitis. Druginduced allergic hepatitis was thought to be mediated by type IV immunological reactions [14].

The fact that some cells of the liver were necrotic showed the toxic nature of the plant extract at a high concentration. Phytochemical analysis of the ethanol extract of $P$. staudtii leaves showed the presence of alkaloids (benzylisoquinoline), glycosides, saponnins, carbohydrate, tannins, flavonoids and resins [15, 16]. Detoxification of these compounds by liver at a high concentration such as $4000 \mathrm{mg} / \mathrm{Kg}$ might have resulted to the inflammation observed. This is because chemicals absorbed following ingestion pass almost exclusively into the hepatic portal vein and are transported to the liver for detoxification. The kidney tissues were also affected showing cellular infiltration still confirming the toxic nature of this plant at a high concentration. Indiscriminate use of this plant for the treatment of malaria by local people without any standard measurement as reported [6] is therefore unacceptable.

However, the aqueous extract of $T$. monadelpha appeared to be less toxic. The histology of the heart and lung tissues showed no lesion to suggest any toxic effect on these tissues even at a high concentration of $4000 \mathrm{mg} / \mathrm{Kg}$. Although, lesions were observed on the liver and kidney tissues of the experimental animals treated with $T$. monadelpha at concentration of $4000 \mathrm{mg} / \mathrm{Kg}$, but there was no necrosis as compared to $P$. staudtii. A study carried out with $T$. monadelpha on the sperm indices and testosterone level of male albino rats showed no toxic effect but rather promoted the mobility and viability of the sperms [17].

\section{CONCLUSION}

The extract of $P$. staudtii appeared to be more toxic than T. monadelpha. Use of these herbal plants by humans need to be standardized. Although, $T$. monadelpha appeared to be safer than $P$. staudtii but indiscriminate consumption of these herbal plants by the local people should be discouraged.

\section{ACKNOWLEDGEMENTS}

The author thanks Dr. O. O. Aina of Department of Veterinary Anatomy, University of Ibadan, and Ibadan, Nigeria for interpreting the histology results of the animal tissues.

\section{REFERENCES}

1. Muhammad, S., \& Amusa, N. A. (2005). The important food crops and medicinal plants of northwestern Nigeria. Res J Agric Biol Sci, 1(3), 254260.
2. Principe, P. P. (1991). Valuing the biodiversity of medicinal plants. The conservation of medicinal plants, 79-124.

3. Pearce, D. W., \& Puroshothaman, S. (1992). Protecting biological diversity: the economic value of pharmaceutical plants (No. 27). Centre for Social and Economic Research on the Global Environment,[1992].

4. Kamatenesi- Mugisha, M., Oryem- Origa, H., Odyek, O., \& Makawiti, D. W. (2008). Medicinal plants used in the treatment of fungal and bacterial infections in and around Queen Elizabeth Biosphere Reserve, western Uganda. African Journal of Ecology, 46, 90-97.

5. Majekodunmi, S. O., Adegoke, O. A., \& Odeku, O. A. (2008). Formulation of the extract of the stem bark of Alstonia boonei as tablet dosage form. Tropical Journal of Pharmaceutical Research, 7(2), 987-994.

6. Olorunniyi, O. F., \& Morenikeji, O. A. (2013). The extent of use of herbal medicine in malaria management in Ido/Osi local government area of Ekiti state, Nigeria. J Med Plant Res, 7(42), 31713178.

7. Olorunniyi, O. F. (2013). In vivo antimalarial activity of crude aqueous bark extract of Trichilia monadelpha against plasmodium berghei berghei (NK65) in mice. Int J Pharm Med Bio Sci, 2(4), 2278-5221.

8. Olorunniyi, O. F., \& Morenikeji, O. A. (2014). In vivo antimalarial activity of crude aqueous leaf extract of Pyrenacantha staudtii against Plasmodium berghei (NK65) in infected mice. African Journal of Pharmacy and Pharmacology, 8(12), 342-345.

9. Gu, J., Weng, Y., Zhang, Q. Y., Cui, H., Behr, M., Wu, L., \& Ding, X. (2003). Liver-specific deletion of the NADPH-cytochrome P450 reductase gene impact on plasma cholesterol homeostasis and the function and regulation of microsomal cytochrome P450 and heme oxygenase. Journal of Biological Chemistry, 278(28), 25895-25901.

10. Akuodor, G. C., Idris-Usman, M., Ugwu, T. C., Akpan, J. L., Irogbeyi, L. A., Iwuanyanwu, T. C., \& Osunkwo, U. A. (2010). Ethanolic leaf extract of Verbena hastata produces antidiarrhoeal and gastrointestinal motility slowing effects in albino rats. Journal of Medicinal Plants Research, 4(16), 1624-1627.

11. Iyiola, O. A., Tijani, A. Y., \& Lateef, K. M. (2011). Antimalarial activity of ethanolic stem bark extract of Alstonia boonei in mice. Asian J. Biol. Sci, 4, 235-243.

12. World Health Organization. (1987). Principles for the Safety Assessment of Food Additives and Contaminants in Food-Environmental Health Criteria 70.

13. World Health Organization. (2000). General guidelines for methodologies on research and evaluation of traditional medicine (No. 
WHO/EDM/TRM/2000.1). World Health Organization.

14. Andrade, R. J., Robles, M., Fernández-Castañer, A., López-Ortega, S., López-Vega, M. C., \& Lucena, M. I. (2007). Assessment of drug-induced hepatotoxicity in clinical practice: a challenge for gastroenterologists. World journal

of gastroenterology: WJG, 13(3), 329.

15. Falodun, A., Usifoh, C. O., \& Nworgu, Z. A. (2005). Phytochemical and active column fractions of Pyrenacantha staudtii leaf extracts on isolated rat uterus. Pakistan journal of pharmaceutical sciences, 18(4), 31-35.

16. Anosike, C. A., Ugwu, U. B., \& Nwakanma, O. (2008). Effect of ethanol extract of Pyrenacantha staudtii leaves on carbontetrachloride induced hepatotoxicity in rats. Biokemistri, 20(1).

17. Oyelowo, O. T., Bolarinwa, O. L., \& Morenikeji, O. A. (2011). Assessment of sperm indices and testosterone level on the effect of Trichilia monadelpha extract in male albino rats. Afr $J$ Pharm Pharmacol, 5, 1956-8. 